\title{
Staying Alive and Finding the Balance - An Interview with Scholar-Translator Dr. Kathryn Hellerstein ${ }^{1}$
}

\author{
Didem Uca \\ University of Pennsylvania, USA
}

The interviewee, Kathryn Hellerstein, is a translator of Yiddish poetry into English, a poet, and a professor of Yiddish at the University of Pennsylvania. Her translations of Yiddish poetry include Paper Bridges: Selected Poems of Kadya Molodowsky and In New York: A Selection of Poems by Moyshe-Leyb Halpern. Published by Stanford University Press in 2014, her monograph AQuestion of Tradition: Women Poets in Yiddish, 1586-1987 was awarded the National Jewish Book Award (Barbara Dobkin Award for Women's).

The interviewer, Didem Uca, is a translator from German and Turkish and a third-year PhD student in Germanic Languages and Literatures and Gender, Sexuality, and Women's Studies at the University of Pennsylvania. Her translations have appeared in New Books in German, Jabrbuch Türkischdeutsche Studien, and as part of an exhibit at the Museum of Stiftung Neue Synagoge - Centrum Judaicum in Berlin. Her research interests include intercultural studies, narratology, and women's writing.

Didem Uca: Thanks for taking the time to meet with me, Kathryn. I wanted to ask first: How did you get started as a poet? As a translator? Did these two passions emerge simultaneously or separately?

Kathryn Hellerstein: Well, I started writing poems when I was seven years old and because no one in my family ever throws anything out, we still have them somewhere, in crayon, and I would never show them to anyone, but they do exist! I was an English major in college and took a lot of poetry classes. I was a very serious poet. I studied with Robert Pinsky at Wellesley and, after I transferred to Brandeis, with Adrienne Rich, Galway Kinnell, and J.V. Cunningham, a great translator of Catullus. But it never occurred to me to translate anything until I took a poetry workshop at Wellesley with David Ferry. One of the assignments he gave us was to translate a poem. I picked a poem by Verlaine [from Romances sans paroles]. Excuse my American-Cleveland-Yiddish-accented French, but it went: "Il pleure dans mon cœur / Comme il pleut sur la ville / Quelle est cette langueur / Qui pénètre mon cœur?" And it was a sonnet, and I didn't try to replicate the rhyme or meter, and I didn't have any sense of artistry as I was doing it. I just did what I could, I used my bilingual dictionary, and I wrote out something and tried to make it sound better, whatever that meant at that time. I went over it a few times, handed in the assignment, and David Ferry wrote on my paper, "This is beautiful," and I had no idea why. That gave me an idea about translation, but I didn't follow up on it seriously until graduate school.

\footnotetext{
${ }^{1}$ The interview was conducted on March 11 ${ }^{\text {th }}, 2015$.
} 
DU: What happened during graduate school?

KH: I went to Stanford to do a Master in English and Creative Writing, and then entered the Ph.D. program, thinking I would study Renaissance poetry. A couple of things happened at Stanford that made me into a translator as well as a poet. I became friends with Darra Goldstein, who's now a distinguished professor of Russian at Williams College. I walked into a party and saw a woman who looked kind of like me, with a lot of very curly hair that was out of control, and it was an instant recognition of a hair mate and a soul mate. She had been studying Dutch, and I had taken a year of German at Brandeis, which I liked, but I didn't really know what to do with it. So she was fiddling around with translating Dutch children's poems. We sat down and played out a few poems together, and it made me think about Germanic languages and the translation of poetry in a very positive and more serious way. So that really got my juices flowing.

DU: When did you start thinking about Jewish themes and Yiddish poetry?

KH: During graduate school, I started to deal with a lot of issues regarding my Jewish identity and was facing the super-WASPy culture of the English department at that time. My department had around fifty tenured professors, with only two women and one Jew. In many ways it was a wonderful place for me, but it was culturally not inclusive for a Jewish woman. I was sort of wandering intellectually after realizing I wouldn't have time to learn the Greek and Latin required to become a Renaissance scholar. At that same moment-this was in 1976-Irving Howe and Kenneth Libo published a book called World of Our Fathers, an intellectual history of Jewish immigrant life in New York from the 1880s to the 1920s. A "grateful patient" had given my father this book, and he sent it to me. I read this book, and my world was changed. I suddenly discovered this American Jewish literature written in Yiddish that I had never known existed. No one in the English department at Stanford had ever heard of it, and I thought: "This is my calling." I had a conversion experience.

At the same time, I was taking an independent study with Donald Davie on American modernism - he was a very important professor for me, because he was a poet, scholar, and translator-and he said, "If you're going to be an American poet, you need to come to terms with Ezra Pound and T.S. Eliot." So I sat and read them all summer long, and on the one hand, I was completely seduced, especially by Pound - his brash, in-your-face tone, and the revolutionary stuff he says about not just blindly or deafly following whatever is popular in your moment or in the preceding generation, but setting forth and discovering new things, and finding other traditions and languages, other aesthetic systems and values to inform your own voice. That's how you'll become a living poet and not just a follower of convention. And Pound tells the young poet to translate. On the other hand, both Pound and Eliot had explicit anti-Semitic messages, in their writing, lives, attitudes. They portrayed Jews as stereotypes, and it was deliberate, because it was part of the ethos of that literary culture. So I'm sitting with my British, Anglican, male professor who was my hero that summer, and I'm reading about the unsavory "jew" [sic] in Hugh Selwyn Mauberly and getting a mixed message: I have 
potential as an American poet, but I'm a young, Jewish woman reading this anti-Semitic nonsense in poetry that I'm being told is important. There was not much of a sense of political correctness then at all. Ethnicity, color, gender-these were terms that were just starting to percolate as relevant to academia.

So in the middle of all this, I became aware of Yiddish literature, and it seemed like it was an answer, a challenge, to Pound's and Eliot's stereotypes. This Jewish literature was variegated, powerful, rich, complicated, complex, and it was all in a Jewish language that was otherwise basically made fun of. I decided to learn Yiddish. I first started to study in an ad-hoc Yiddish grammar seminar through the Linguistics department taught by Ray Finkel, a computer scientist, in his grad student apartment. I was 24 or 25, and I would have to sit on the floor because there weren't enough chairs and I was the youngest. We used Weinreich's College Yiddish textbook. I gobbled up the grammar but was terrified of speaking the language. Then I decided to go to the YIVO-Columbia summer immersion program in Yiddish. That was a life-changing summer, the summer of '77.

I then somehow had the chutzpah to convince my department that I was going to write a translation dissertation on Yiddish-American poetry. I was one of very few people to propose to do a translation dissertation and certainly the only one to take on Yiddish. Jewish-American literature was hardly considered a field at the time. There's major institutional support for this at Stanford now, of course, (a world-class Jewish Studies program and the Jewish History and Culture series published by the Press), but there was very little at the time. So I did a translation of Moyshe-Leyb Halpern's first book, In New York, and wrote a series of essays on it, on the poetry and the process of translation.

DU: Why do you think your department allowed you the freedom to take on a non-traditional project?

KH: The reason I was able to get away with this do-it-yourself field and dissertation was that in the late 70s, this was exactly when the great theoretical revolution was taking place in literature. The French School and deconstructionism were bubbling to the surface, as well as ethnic studies and throwing English literature departments into disarray. So it was 'of the times,' in a sense. And I was fortunate to find teachers and mentors both at Stanford and from afar-in Cleveland, New York, and Jerusalem.

DU: You've taught translation courses for many years and have worked with hundreds of students with different language backgrounds. Do you think that an instructor has to know a student's source language in order to serve as a mentor?

KH: My dissertation advisor and lifelong mentor and dear friend John Felstiner didn't know Yiddish, but he was very interested in Jewish literature and in translation. He taught a terrific translation workshop right at the end of my course work that was hands-on, a really serious graduate writing workshop on poetry translation. We read Walter Benjamin and George Steiner. There were students doing many different languages. I got to expose how little I knew about anything, and got tough but very helpful feedback in a safe environment. John made it very warm and positive. The tone was one 
of inquiry rather than of damnation and judgment-which there's plenty of in graduate school and academia.

DU: I'd like to ask about one of your other mentors. I know that Yiddish poet Malka Heifetz Tussman had a big influence on you, especially on your early translations of Yiddish poetry. Can you tell me about how that relationship started and what kind of an impact it had on your career?

KH: My friend Marcia Falk, who had been working closely with Malka, introduced us. I would drive up to Berkeley every Friday from Palo Alto, and we would sit for most of the day, cook a modest preShabbos lunch together and study Yiddish poetry. That went on from '77 to '82 when I left California. Our friendship continued until she died in '87.

This was all while writing my dissertation on Halpern, whom Malka really didn't like. She thought he was vulgar, and she turned me on to her own poetry and that of other women poets in reaction to my scholarly, modernist, prejudice towards male poetry. I wasn't a feminist yet, so I sort of bought into the hierarchy that academia presented. There were a lot of women graduate students but not many women professors. I didn't question it, somehow. It was a fraught time.

She was one of the most important teachers I ever had. She didn't have a $\mathrm{PhD}$ or an academic position, and that just shows you that you can do a lot with your life in literature without being crowned or knighted or circumcised, whatever it is the academic hierarchy does to you when you become a professor. My time with Malka made me into the scholar and translator I am today.

DU: How do your translations affect your readings of poetry and vice versa?

KH: What I discovered, in the process of translating Halpern and starting to work on the women poets, like Kadya Molodowsky, translating is an incredible, intimate way to read closely. Closereading was really the mode of literary interpretation that I learned from my college teachers, who had been trained in New Criticism. Though it stopped being fashionable long ago, it teaches the basic tenets of close-reading-I no longer believe in isolating the poem, the text as its whole world, because you need context to translate!-but close-reading is still my touchstone. I like concrete things. I'm a painter, I like to make things with my hands. I'm a thing person, like an ethnographer. I like to see that carved, mysterious, foreign object in front of me, even if I don't know what it is, I know I can find something out by looking at it, and get beyond it by going into it. That's how I read poetry. So there's no more intimate way, no more concrete way, to deal with the thing of a poem than to translate it.

Even as an undergraduate, when I had to learn how to write papers about poetry, when I had horrible writer's block, one of my teachers told me that paraphrasing a poem, word by word, line by line, was a way of starting to crack it open, to ask questions and form connections that would lead me to develop a voice and have something to say about the poem. Paraphrase, I would say, is a form of translation, from the poet's language on the page to my language on my page. Translation is a more 
precise form of paraphrase. You have to become the ventriloquist of the poet. I really do read through translation. And I translate for readers who I hope will go back and read the original.

DU: How does your theoretical engagement with translation studies impact your own translation work? Are you thinking of Schleiermacher when you're translating a poem?

KH: Of course translation theory is a booming field, and there is much I find of interest-I teach and write about it. But, no, I'm not actually thinking of any theory when I'm translating. The most important scholarly works for me when I'm translating are the dictionaries-Harkavy, Weinreich, Bienfeld and Bochner, Der Groyser Verterbukh fun der Yidisher Shprakh, and Stutchkoffs thesaurus. I also use medieval and modern German dictionaries, Polish, Russian, biblical and modern Hebrew dictionaries. The act of translation is one of intimate engagement with the words on a page and with the constant sense of my own inadequacy. By constantly checking in the resources I have, the verterbikher and the oytser, the dictionaries and the thesaurus, I find context and clues and a key to start unlocking the text- those are my scholarly references. It goes without saying that I am always reading Yiddish literature—poetry, fiction, memoirs, plays—which provides cultural context.

Some of the translations I've done, I get stuck on a particular cultural aspect that I don't understand. Like this one time, probably fifteen years ago, I was translating poems with references to different articles of clothing, but I couldn't find definitions of them in any of my dictionaries, especially of the women's clothing. I didn't know what they looked like until I went to a material cultures exhibit at Beit Hatefusot, the Museum of the Jewish Diaspora at Tel Aviv University. I saw this clothing on display_kerchiefs for covering a woman's hair and brow, special embroidered collars for covering the neck and breasts — and finally understood what these writers were referring to. Poems by many of these poets, such as Molodowsky, Miriam Ulinover, Rokhl Korn, are grounded in a particular cultural moment and a way of life-and some of these words specific to women's lives and bodies weren't deemed important enough to make it into the dictionaries and encyclopedias. Or the men who compiled the dictionaries didn't know about such intimate details of women's lives. Seeing an object in a museum can change my world and can help me go back to a translation and make it better.

So I don't think of theory, but maybe a theory evolves out of my translations over time. In translating, revising, double-checking, revising again, I write lots of questions down and footnotes as I'm translating. I look up everything I don't know and even things I think I know, because sometimes they're different than what I'm assuming they are. It's a humbling engagement with the text, and as best I can, I use all of the resources of language and culture I can get my hands on.

DU: It's clear to me that your approach to translation involves immense research, but translations are often not seen as valid scholarly contributions. What advice would you give to emerging scholartranslators on how to navigate this dynamic? 
KH: If you think about it, translation was a part of every boy's education in Europe for centuries. They read Latin and Greek by translating them into vernacular languages, as an exercise of language learning. Even earlier, in religious life, the Hebrew Bible was not a vernacular text by the time it got canonized, because nobody spoke biblical Hebrew anymore. The sacred texts got translated. Translation is right at the foundation of the Western, Judeo-Christian trajectory, at the absolute centre of religious, cultural, institutional life. Though translating the Bible, while essential, was also ideologically driven and could be very dangerous, because it had so many implications about who controlled access to the sacred word. Translation was an essential tool in a classical education. The process of translation was bound into religious and secular education and institutions. But it was not valued within the academic hierarchy until fairly recently, when people started writing about the process of translation, and theories of translation began to be collected and studied.

The Modern Language Association has recently acknowledged translation as a legitimate academic activity, and even used it as a convention theme. There is also a great organization called the American Literary Translators Association. But a scholarly, critical translation, with an introduction, notes, and bibliography, is still not considered seriously enough in the tenure file. I really appreciate [Lawrence] Venuti's advocacy for translators at the university. One of the points that he makes is that our world would be very narrow if we didn't have translations. It's a huge blind spot among academics, who assume that, as in the story by Jorge Luis Borges, "Pierre Menard, Author of the Quixote," that translation is just derivative. People still tend to take translations for granted.

So advice for the young translator would be to know what you're getting into. Know that it may not help you in your career, but do it anyway. Actually, once I was kvetching to Malka, sitting at her round dining room table, eating chicken we had made in her little broiler oven for lunch, that I would never write another poem. She told me to stop complaining, and said, "A poem will come to you when the poem needs you." And years earlier, David Ferry, when he first introduced that translation exercise in that undergrad class, said that when you're writing poetry and you have a dry spell, translate a poem by somebody else instead, because, A) you don't have to worry about what's being said, you just have to worry about how to say it, and B) you keep your poetic chops choppy. (That's my diction, not his!) And you get to pretend you're a great poet, by writing a great poet's poem in your own words. So I would say to the young-or old-scholar or writer: when you're stuck, translate something. It unsticks you. It keeps you alive, it keeps you engaged. You're in conversation with somebody else from another moment, another time, another language, through the page. You produce something of your own which puts you into a dialogue with another poet from another place and time.

You have to balance out the careerist nonsense with your own needs as a creative scholar, writer, and thinker. And it's hard to achieve the balance and keep it all going, but translation can be a really helpful exercise. If you catch the bug to translate, it can keep you exercised, get you exorcized, and keep you creatively alive in a really wonderful and profound way. 
DU: I would like to ask you now about your positionality as a female poet and translator of works written by women, particularly from Yiddish, which presents an interesting gender dynamic. While Yiddish, the vernacular language of the Ashkenazi Jews, is considered the mame-loshn or mother tongue, to be used in the home, in contrast to the religious and scholarly language of Hebrew, which women could often not read, it was also reclaimed during the Haskalah [Jewish Enlightenment] and beyond into the $20^{\text {th }}$ century as a language of literature, thereby ironically excluding women, for whom Yiddish was often the primary literary language (in addition, in some cases, to local vernacular languages). Does this gender dynamic impact your academic or creative engagement with Yiddish?

KH: I came to the project of my book $A$ Question of Tradition-which took some 25 years to dowhen I was studying with Malka, becoming acquainted with women poets in Yiddish. As I matured, got my first job, and started my adult life, it was hard not to become a feminist. Once you start thinking about writers and gender, there are a lot of issues that you have to deal with-sexuality, gender roles in that culture, the whole issue of pre-modern Yiddish being a language of women's devotional writings and also a language for men who were not scholars and did not understand Hebrew. I've been really interested in connections that are both tenuous and strong between the devotional literature and the assumptions about women's lives lived within a devotional context and the rebellious, modern, presumably secular literature that women and men ended up writing as they rode the wave of the Enlightenment, post-Enlightenment, and Modernism in the late $19^{\text {th }}$ and early $20^{\text {th }}$ century. Part of the politics of translating is choosing what to translate and finding a publisher who is willing to publish the translations - and that's not so simple. There have been volumes of Yiddish women's writing in translation in the last few decades, but there is still a lot that has not been translated or published.

DU: There's also a catch-22 though that I'd like to point out. On the one hand, women writers are often excluded from syllabi and academic discussions on Literature with a big $L$, so courses and publications that focus on their artistic contributions are of utmost importance in creating a space to engage with their texts. On the other hand, teaching or producing academic work on women writers as a group can be problematic because it views them in terms of their positionality as women first and foremost, using the same ideology that excluded them from the mainstream in the first place. One could make a similar argument about Jewish writers. Why did you decide to publish an anthology of women writers in translation? Do you think setting these writers off into their own publication adds to the ghettoization of women writers, of Jewish writers, of Yiddish writers?

KH: In 1928, when Ezra Korman published Yidishe dikhterins: Antologye, the book flopped. He had hoped it would be a bestseller. One poet, Melekh Ravitsh, wrote a nasty review at the time, joking that Korman must have slept with most of the women he included in the book, even authors of tkhines [paraliturgical prayers] writers from 300 years prior. There was an atmosphere of hostility towards women writers. So, yes, there is a problem with making an anthology of or writing a book about women poets as women poets. But on the other hand, if you don't, then nobody will see them. So why not get a few people annoyed and instigate some discussion? Why not have a place to put the 
translations and scholarship about these basically unknown, underappreciated authors, and get them out into the world?

In terms of my teaching, I actually teach only one undergraduate and one graduate course specifically on Jewish women as writers and readers. In my other courses, I always integrate many women writers playing all different roles. Why not do both-integrate and separate to draw attention to these writers and their works and make them a part of the greater cultural and literary picture? Nothing has to be either/or.

DU: Both/and.

KH: The more the better. Years ago there was this whole anxiety that if you don't teach the canonwhatever the canon is - then you'd replace the canon with minor writers. This whole bogus notion of hierarchy. Read more, learn more. Read Plato and Kadya Molodowsky. Read Goethe and Rilke, and Sholem Aleichem and Malka Heifetz Tussman.

DU: And Kathryn Hellerstein! 